\title{
Analysis of the Productive, Structural, and Dynamic Development of Augmented Reality in Higher Education Research on the Web of Science
}

\author{
Jesús López Belmonte $\mathbb{D}^{\mathbb{D}}$, Antonio-José Moreno-Guerrero ${ }^{\mathbb{D}}$, Juan Antonio López Núñez ${ }^{\mathbb{D}}$ and \\ Santiago Pozo Sánchez * (D) \\ Department of Didactics and School Organization, University of Granada, 18071 Granada, Spain; \\ jesuslopez@ugr.es (J.L.B.); ajmoreno@ugr.es (A.-J.M.-G.); juanlope@ugr.es (J.A.L.N.) \\ * Correspondence: santiagopozo@correo.ugr.es
}

Received: 14 November 2019; Accepted: 2 December 2019; Published: 5 December 2019

\begin{abstract}
Augmented reality is an emerging technology that has gained great relevance thanks to the benefits of its use in learning spaces. The present study focuses on determining the performance and scientific production of augmented reality in higher education (ARHE). A bibliometric methodology for scientific mapping has been used, based on processes of estimation, quantification, analytical tracking, and evaluation of scientific research, taking as its reference the analysis protocols included in the Preferred Reporting Items for Systematic reviews and Meta-analyses for Protocols (PRISMA-P) matrix. A total of 552 scientific publications on the Web of Science (WoS) have been analyzed. Our results show that scientific productions on ARHE are not abundant, tracing its beginnings to the year 1997, with its most productive period beginning in 2015. The most abundant studies are communications and articles (generally in English), with a wide thematic variety in which the bibliometric indicators "virtual environments" and "higher education" stand out. The main sources of origin are International Technology, Education and Development Conference (INTED) Proceedings and Education and New Learning Technologies (EDULEARN) Proceedings, although Spanish institutions are the most prolific. In conclusion, studies related to ARHE in the WoS have become increasingly abundant since ARHE's research inception in 1997 (and especially since 2009), dealing with a wide thematic variety focused on "virtual environments" and "higher education"; abundant manuscripts are written in English (communications and articles) and originate from Spanish institutions. The main limitation of the study is that the results only reveal the status of this issue in the WoS database.
\end{abstract}

Keywords: augmented reality; higher education; scientific production; web of science; bibliometric analysis; scientific mapping

\section{Introduction}

Technology is currently in a moment of great development in the field of education, as a result of the continuous advances that are occurring in techno-pedagogical matters that promote its inclusion in learning spaces [1], where technology is increasingly attaining greater use in training activities [2] thanks to its ubiquitous and ergonomic nature [3]. All this has led to new student activities, not only in the way they communicate and collaborate with their teachers and peers but also in the way they interact with contents in a digital way [4].

Educational technology has managed to stimulate the teaching and learning process by enriching interactions with information [5], thereby creating a benefit in the essential aspects of teaching, such as student interests, motivation, and participation [6]. This current educational landscape has conditioned 
the professional practice of teachers and is visible in the need to carry out innovative practices [7] according to the requirements of an education immersed in this digitalized era [8].

In this sense, the digital competency of teachers has become especially relevant in their daily tasks [9]; indeed, teachers are at the forefront of the education of new generations of students who are highly familiar with technology [10]. Despite this, current students still have certain training lacunae in related professional competences [11]. Therefore, it is required that teachers integrate of knowledge and skills linked to technopedagogy-that is, a new methodological paradigm in which the materials and resources used in the teaching and learning processes are mostly technological and digital. This will improve quality indicators and reproduce innovative learning experiences in the hands of educational technology [12].

One of the technologies with great promise in the field of education is augmented reality (AR) $[13,14]$, which allowing for unique instructional activities to facilitate learning [15]. Experts define this technology as an innovation that "allows the combination of digital information and physical information in real time through different technological devices" [16] (p. 5), thereby promoting access to expanded information about us through mobile devices [17]. The literature shows that AR is a resource that can be used in different educational stages, from the initial stages of school [18] to higher education [19].

Likewise, AR offers a series of potential benefits in the learning process, such as the assumption of a greater role for the student [20], an increase in the student's motivation [21], self-regulation [22], and interest in a task [23], and the exploration of teaching materials and content [24]. AR also encourages digital competition [25] and promotes the development of significant, constructivist, collaborative discovery, and ubiquitous learning [26-28]. These benefits favor both the improvement of teaching results and the environment of training spaces [29].

There has not been a significant number of articles reporting on AR. The main findings of related research have focused on quantifying their scientific productions [30], new technological trends analyzed by researchers [31], and the changes and advances produced by this type of teaching approach [32]. Other studies have focused on the country (Spain) and the time period (2015-2017) for greater scientific production [33]. Likewise, other research has focused on specific fields of education, such as engineering, science [34], the business field [35], and education through applications related to tourism, entertainment, marketing, and transport, among others [36].

Bibliometric studies on AR represent a booming area of study, but much remains to be explored. Bibliometric studies on AR are currently limited, and this has produced a research gap [3] that can only be resolved by enhancing research in this field of study. In a recent study focused on the field of education, a bibliometric analysis carried out on the Web of Science (WoS) has confirmed that the most prolific period is 2015-2017, with Spain being the country with the highest growth production in this field [33], followed by Taiwan [37]. This latest study also found that Taiwan University of Science and Technology is the main institution producing related research, and that C.C. Tsai and G.J. Hwang are the most important authors [37].

In a bibliometric study on AR carried out for the field of business administration, two distinct periods were differentiated in terms of the amount of scholarship produced; the most prolific period corresponds to 2012-2016 [35]. It has been found that quantitative studies predominate [38], especially in communication and presentation formats (moreso than articles [3]), with English being the most widely used language [33]. A combined bibliometric study between AR and M-learning on the WoS found that there is a great variety of main topics being analyzed, with the concept of the phenomenon, the development of new AR methodologies, motivations, special relocations, and the subjects in which AR is implemented being the most popular [32]. A bibliometric study in the specific field of education highlighted that "learning/academic achievement", "motivation", and "attitude" are the most examined variables [38]. 
The motivation of this study was to investigate the concept of AR in high-impact literature focused on higher education from a novel methodological perspective, with the purpose of achieving new results and deepening existing ones.

The structure of this work follows the methodological process of bibliometric studies. After the presentation of the state of the matter in the analyzed literature, this manuscript continues by drafting the materials and methods used during the investigation, formulating the justification and objectives of the study, and explaining the procedure and data collection. Then, the results related to performance and scientific production, structural and thematic development, the thematic evolution of the terms, and the authors with the highest relevance index are presented. Finally, we present a discussion of the results of the scientific literature we found and offer a set of final conclusions for the entire research process.

This study is limited to analyzing AR in higher education, specifically in the Web of Science, which is the only database we explore. The reason for this study lies in the need to lay the foundations for the scientific development of AR in a university environment, since no precedent has been found in the specialized literature on the state of the question formulated in this investigation. This is the main problem to be solved in this research paper.

Due to the relevance assumed by this emerging technology, and given the benefits of its use in learning spaces, this study is focused on the analysis of scientific productions on augmented reality in higher education (ARHE). The objectives set out in this study are focused on:

1. Evaluating the performance of and scientific productions on ARHE.

2. Establishing the scientific evolution of ARHE in the specialized literature.

3. Discovering the most important topics in the scientific literature on ARHE.

4. Identifying the most relevant authors who study ARHE.

\section{Materials and Methods}

\subsection{Research Design}

In order to develop the present study and achieve the formulated objectives, a research methodology of a bibliometric nature has been used, starting from a foundation of previous studies reported in the scientific literature. The use of this research technique lies in the potential reflected by scientometrics, which refers to the quantification, evaluation, and estimation of scientific developments in a specific field of knowledge. This paper examines the evolution of the structure and dynamism of the concept of augmented reality in higher education through an analysis of co-words. In order to do this, the h-index has been taken into account, as well as the citation volume, giving rise to an elaboration of a science map that allows us to observe the yield and locate and determine the terminological subdomains of this field of study, thereby representing the evolution of the subject in specialized literature [39,40]. Also, using the analysis protocols included in the PRISMA-P matrix as a reference, analytical tracking and document measurement techniques have been used through the establishment of different literary control variables. In the same way, the issues concerning AR and its research development have been located through scientific mapping [41,42].

\subsection{Procedure, Debugging, and Data Analysis}

The present study has been carried out following the structured protocol for different actions. First, the database in which to search for scientific publications was chosen: the Web of Science (WoS), which is a repository that houses a large number of high-impact scientific materials.

The second process is linked to the action of searching for and reporting documents. To carry out this action, the keywords to be used were delimited. These keywords were selected after consulting the ERIC and UNESCO thesauri, in order to obtain the agreed-upon and standardized terms among the scientific community. The main keywords entered in the WoS search field were "augmented reality" and 
"higher education", which formed the following search equation: (("augmented reality") AND ("higher education") OR ("university") OR ("universities") OR ("colleges") OR ("postdoctoral education")). This algorithm encompassed the entire literary volume (not limited by time period) and focused on the metadata containing titles, abstract, and keywords of publications. The document-reporting process began in May 2019 and ended in August of the same year, resulting in a total of 555 documents-as an analytical unit-that met the inclusion criteria established in Table 1, which have been established to show the most relevant aspects of each. The inclusion criteria for each of the indicators have been developed to show a considerable number of elements, never showing the totality of elements. After checking them (repeated or incorrectly indexed documents), a figure of 552 scientific publications was obtained (Figure 1).

Table 1. Production indicators and inclusion criteria.

\begin{tabular}{cc}
\hline Indicators & Criteria \\
\hline Year of publication & All documents are contemplated \\
Language & All languages are contemplated \\
Publication Area & $x \geq 15$ \\
Type of documents & All documents are contemplated \\
Organizations & $x \geq 5$ \\
Authors & $x \geq 4$ \\
Sources of Origin & $x \geq 6$ \\
Countries & $x \geq 15$ \\
Citation & The five most cited documents \\
\hline
\end{tabular}

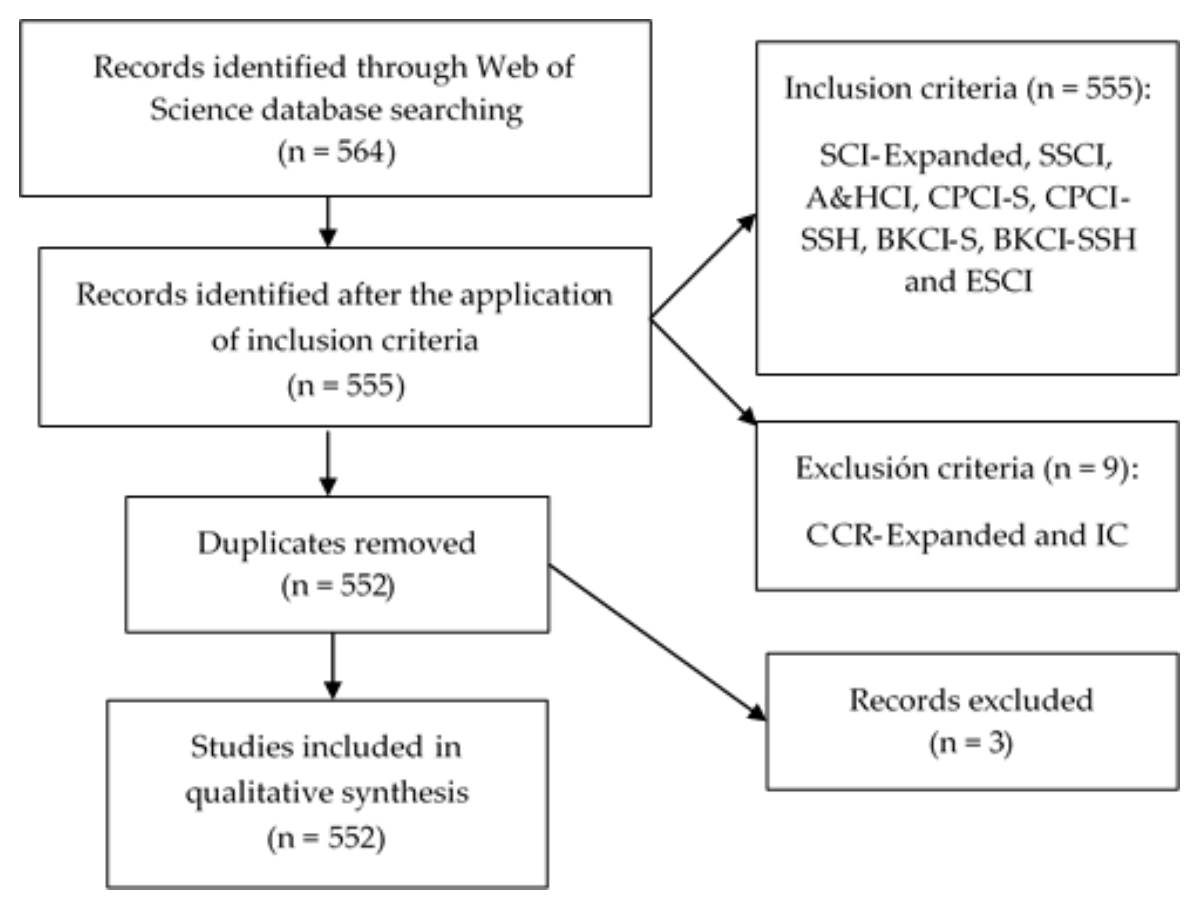

Figure 1. Flowchart according to the PRISMA Declaration.

Co-word analysis has been used to carry out a structural and dynamic study [43], paying special attention to the h-index, among other indicators of scientific quality [44]. This analysis gave rise to a science map that allowed us to study the performance and evolution of AR in the literature and AR's impact on higher education. Likewise, the locations of the subdomains of the concept in this field of research were determined.

Data analysis has been deployed through various programs. Specifically, the analysis of results and creation of the citation report for performance analysis, taking into account the year, type of 
document, institution, authorship, means of publication, country, language, and document with the most citations. On the other hand, the SciMAT software has been used to develop the structural and dynamic analysis of longitudinal cutting derived from the co-word technique. This program has facilitated the realization of the following processes.

Recognized themes: Based on the 555 references on ARHE, scientific mapping has been carried out to specify the documents that house the state of the art defined in the present study, avoiding non-AR publications in the university field. Thus, a review of the reported literature allowed us to purify the results, eliminating repeated documents and obtaining a figure with 552 works related to ARHE, which served to make co-occurrence connections through nodes, thereby forming a network of co-words through a clustering algorithm.

Reproduced themes were determined through a strategic diagram and a thematic network in two dimensions (centrality and density). This is articulated in four sectors:

1. Upper left: entrenched but isolated issues;

2. Upper right: motor and essential issues;

3. Bottom left: issues that are a priori booming or, on the contrary, are disappearing;

4. Bottom right: poorly developed and transversal issues.

Determined topics: Developed based on an analysis of the evolution of the nodes in different periods of time, configured as follows for the analysis of co-words: P1 $=1997-2015$ and P2 $=2016-2019$. The reason that they have been limited in such a way is justified by the fact that they cover a minimum of 200 references in temporary spaces. For the authors, a single period (PX) was selected, which compiles all the years of production. Likewise, the strength of association is obtained by the volume of keywords found in common between the different periods.

The assumed performance has been verified through the links established between the keywords and other terms that mark the trend of the node, revealing the use that the scientific community makes of them. A number of aspects have been taken into account. The analysis unit marks the unit of valuation, which in this case refers to the key words marked by the authors in their scientific texts and the key words given by the WoS in relation to those scientific texts, in addition to those of the authors of the various documents. The frequency threshold reflects the minimum frequency threshold for each period, taking into account keywords that appear in at least two documents (for the first period) and three in the second period. The network type reflects the type of network that is going to be built-in this case, a network of the co-occurrence of keywords and authors, or co-word and co-author. The co-occurrence union value threshold establishes the marked periods-in this case, two periods for the keywords and all the years of production for the authors. The normalization measure marks the union threshold, which is the minimum link for that co-occurrence, taking into account unions with a value greater than or equal to 1 in the first and second period (for the keywords) and of 2 (for the authors). The normalization measure marks the measure of similarity used to normalize the network, in this case, the equivalence index eij between two entities, $I$ and $j$, is calculated in the following way: $e i j=c i j 2 / \operatorname{Root}(c i-c j)$, where $c i j$ is the number of co-occurrences of $i$ and $j$ in the set of documents, $c i$ is the number of occurrences of $I$, and $c j$ is the number of occurrences of $j$. The clustering algorithm denotes the grouping algorithm used to obtain the map and its associated clusters or themes and subnets. In this case, the simple centers algorithm is used, where the returned clusters are assigned a label that corresponds to the most central node of the group, with no additional processes necessary to assign labels to the group. The evolutionary measure marks the similarity measure needed to construct the evolution map - in this case, the Jaccard Index and the transition map-in this case, the inclusion index, which is reflected in Table 2. 
Table 2. Production indicators and inclusion criteria.

\begin{tabular}{cc}
\hline Configuration & Values \\
\hline Analysis unit & Keywords authors, keywords WoS \\
\hline Frequency threshold & Keywords: P1 $=(2)$, P2 $=(3)$ \\
Authors: PX $=(2)$
\end{tabular}

Note: P1: The period from 1997 to 2015; P2: the period from 2016 to 2019; PX: the period from 1997 to 2019.

\section{Results}

\subsection{Performance and Scientific Production}

Scientific production on ARHE $(n=552)$ dates back to $1997(n=2)$ and has remained uninterrupted until the present, albeit with a variable amount of documentation, which is irregular from $1998(\mathrm{n}=1)$ until $2014(n=23)$, due to increases and decreases in publications (1999-n $=1 ; 2000-n=5 ; 2001-n=2$; 2002- $\mathrm{n}=4 ; 2003-\mathrm{n}=5 ; 2004-\mathrm{n}=4 ; 2005-\mathrm{n}=6 ; 2006-\mathrm{n}=6 ; 2007-\mathrm{n}=2 ; 2008-\mathrm{n}=6 ; 2009-\mathrm{n}=10$; $2010-\mathrm{n}=18 ; 2011-\mathrm{n}=15 ; 2012-\mathrm{n}=29 ; 2013-\mathrm{n}=25)$. On the other hand, from $2015(\mathrm{n}=52)$ onwards, the ascent is prominent $(2016-n=70 ; 2017-n=94 ; 2018-n=111 ; 2019-n=61)$.

Figure 2 shows the evolutionary development of ARHE throughout its history in the scientific literature. This figure shows three clearly differentiated periods. During the first period, which covers from 1997 to 2007, there is low and uniform production. During the second stage, from 2008 to 2014, the level of production rises irregularly. Finally, in the third period, the production is ascending and more abundant compared to previous periods. The development for 2019 is not significant, since the natural end of the year has not yet occurred, with the literature being open to the publication of new scientific works.

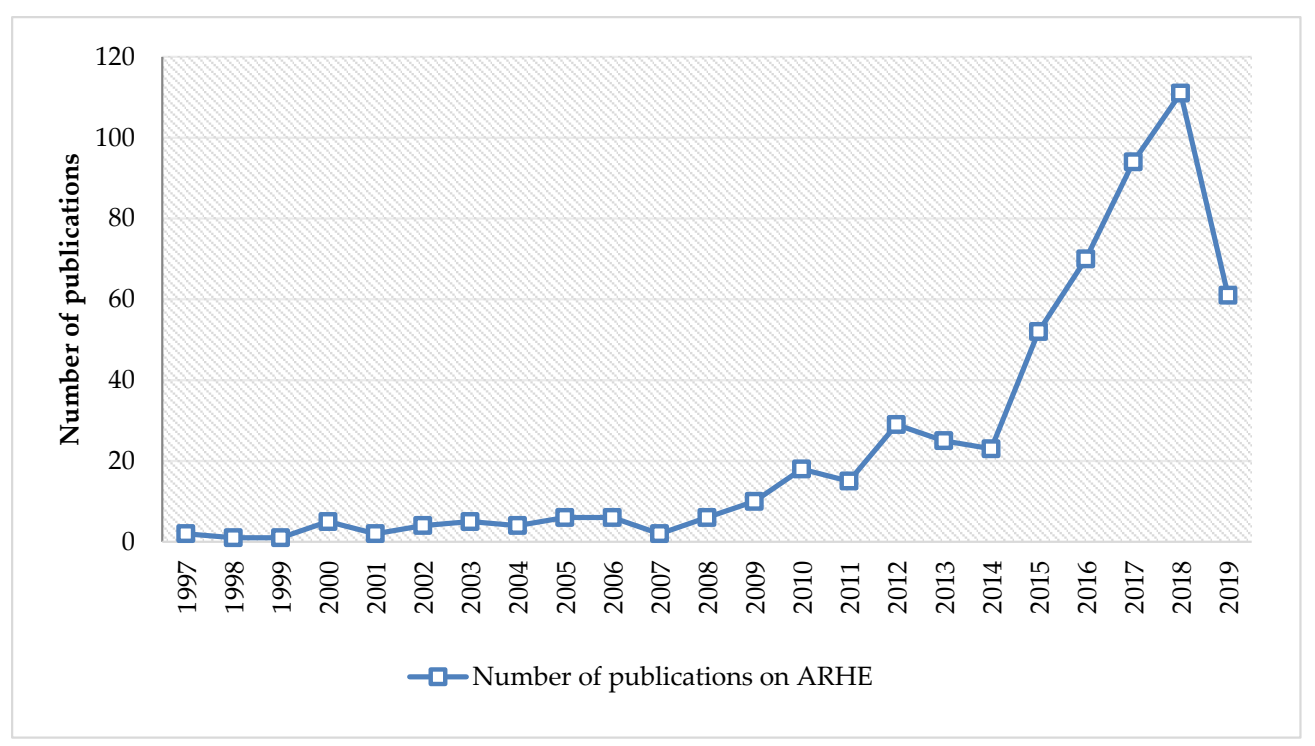

Figure 2. Evolution of scientific production of augmented reality in higher education in the Web of Science (WoS). 
English ( $n=504)$ is positioned as the reference language used by various researchers to show their results to the scientific community, followed, to a lesser extent, by Spanish $(n=41)$, Turkish $(n=3)$, Portuguese ( $(n=2)$, Russian ( $n=2)$, Chinese $(n=1)$, French $(n=1)$, and German ( $n=1)$.

Regarding areas of knowledge, a reference was not obtained for studies related to ARHE, since both "education educational research" $(\mathrm{n}=220)$ and "computer science" $(\mathrm{n}=208)$ show similar results. ARHE is also revealed to be a topic of interest for various fields of knowledge, such as "engineering" $(\mathrm{n}=144)$, "telecommunications" $(\mathrm{n}=26)$, "business economics" $(\mathrm{n}=20)$, "social science other topics" $(n=17)$, optics $(n=16)$, and "imaging science photographic technology" $(n=15)$.

For type of document, the scientific community most commonly chooses communications $(n=315)$ to show the results of their research, followed, to a lesser extent, by articles $(n=235)$, book chapters $(n=10)$, literature reviews $(n=9)$, quick access materials $(n=2)$, and editorial materials $(n=2)$. Spanish companies have been verified as reference institutions for ARHE, given their position in Table 3. Of these, the University of la Laguna and the University of Seville are the most common world-wide references on the state of this topic.

Table 3. Institutions of the origin of the manuscripts on the Web of Science (WoS).

\begin{tabular}{cc}
\hline Institution & $\mathbf{n}$ \\
\hline Universidad de La Laguna & 17 \\
Universidad de Sevilla & 15 \\
Universidad de Córdoba & 8 \\
Universitat Ramon Llull & 8 \\
Polytechnic University of Catalonia & 7 \\
Universitat Politécnica de Valencia & 7 \\
Universidad de Huelva & 6 \\
National Chiao Tung University & 5 \\
National Taiwan University of Science Technology & 5 \\
RWTH Aachen University & 5 \\
State University System of Florida & 5 \\
Universitat D' Alacant & 5 \\
University of Cambridge & 5 \\
\hline
\end{tabular}

The most prolific authors include Martín-Gutiérrez, J. ( $\mathrm{n}=11)$, Fonseca, D. ( $\mathrm{n}=10)$, Redondo, E. $(n=9)$, and Cabero, J. $(n=7)$. Next most productive are Carrera, C.C., Contero, M., Robles, B.F., and Sánchez, A., with five publications, respectively. Finally-complying with the inclusion criteria-Alcaniz, M. has published four works.

"INTED proceedings" is the source of origin with the highest production, followed at a considerable distance by "EDULEARN proceedings" and the other sources listed in Table 4.

Table 4. Source of the origin of manuscripts related to augmented reality in higher education in the WoS.

\begin{tabular}{cc}
\hline Source & $\mathbf{n}$ \\
\hline INTED Proceedings & 20 \\
EDULEARN Proceedings & 13 \\
Lecture Notes in Computer Science & 12 \\
Proceedings of SPIE & 12 \\
Procedia Computer Science & 10 \\
Procedia Social and Behavioral Sciences & 8 \\
Advances in Intelligent Systems and Computing & 6 \\
Business Horizons & 6 \\
Edmetic & 6 \\
Iceri Proceedings & 6 \\
INTED 2016 10th International Technology Education & 6 \\
and Development Conference & \\
\hline
\end{tabular}


For countries with greater scientific production, Spain is a worldwide reference for ARHE, since it occupies a high literary volume $(\mathrm{n}=103)$. Spain is accompanied by the United States, with 68 publications. In second place, there are many other countries, including England $(n=36)$, China $(n=27)$, Taiwan $(n=23)$, Australia $(n=22)$, Italy $(n=22)$, Germany $(n=20)$, Romania $(n=20)$, Turkey $(n=20)$, Mexico $(n=18)$, Canada $(n=15)$, and Malaysia $(n=15)$, whose production levels are lower.

The scientific reference document for ARHE is an article by Kaufmann and Schmalstieg (2002), due to its high number of recorded citations. The rest, although they are worldwide references, have accumulated lower citation figures (Table 5).

Table 5. Most cited articles.

\begin{tabular}{cc}
\hline Reference & Citations \\
\hline Kaufmann, H.; Schmalstieg, D. [45] & 194 \\
Martín-Gutiérrez, J.; Saorín, J.L.; Contero, M.; Alcaniz, & 114 \\
M.; Pérez-López, D.C.; Ortega, M. [46] & 89 \\
Akcayir, M.; Akcayir, G. [47] & 83 \\
Potkinjak, V.; Gardner, M.; Callaghan, V.; Mattila, P.; & 73 \\
$\quad$ Guetl, C.; Petrovic, V.M.; Jovanovic, K. [48] & \\
Andujar, J.M.; Mejías, A.; Márquez, M.A. [49] & \\
\hline
\end{tabular}

\subsection{Structural and Thematic Development}

The longitudinal view is shown in this case on the transition map. This type of map allows us to detect the evolution of the clusters along different periods, as well as the student, the transient, and new elements of each period. This is reflected in the evolution of key words (Figure 3). By analyzing this figure in depth, two circumferences can be observed. These circumferences represent each of the periods analyzed. From left to right, the first refers to the dates established between 1997 and 2015, and the second refers to the period marked between 2016 and 2019.

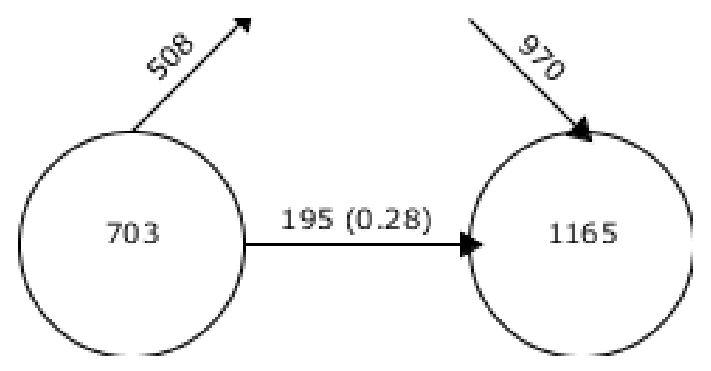

Figure 3. Continuity of keywords between contiguous periods.

In the first circumference, there are 703 keywords. At the top, there is an ascending arrow indicating the number of keywords that will not appear in the second period. The horizontal arrow coming out of the first circumference in the direction of the second one marks the number of coincident keywords in both periods. In this case, a total of 195 represents $28 \%$ of the total for both periods. The second circumference has 1165 registered keywords. The descending arrow above reflects the number of new keywords that are incorporated and did not appear in the first period. In this case, there is a total of 970 keywords.

The thematic diversity in the periods established in this study is wide. In the first period, "virtual environments" is the theme with the highest bibliometric values. Other topics offer similar results. In the second period, a pattern similar to the first occurs, highlighting only "higher education", since other topics belong to indicators with a certain degree of similarity (Table 6). 
Table 6. Thematic performance.

\begin{tabular}{|c|c|c|c|c|c|c|}
\hline \multicolumn{7}{|c|}{ Period 1997-2015 } \\
\hline Denomination & Works & h-Index & g-Index & hg-Index & q2-Index & Citations \\
\hline Development & 3 & 3 & 3 & 3 & 7.75 & 56 \\
\hline Tailored optical fibers & 3 & 3 & 3 & 3 & 7.75 & 56 \\
\hline Pedagogy & 5 & 2 & 3 & 2.45 & 4.9 & 24 \\
\hline Teachers & 4 & 4 & 4 & 4 & 9.8 & 92 \\
\hline Usability & 5 & 3 & 3 & 3 & 7.55 & 51 \\
\hline Instruction & 5 & 3 & 3 & 3 & 7.35 & 54 \\
\hline Virtual environments & 12 & 7 & 9 & 7.94 & 18.52 & 492 \\
\hline Visualization & 9 & 4 & 7 & 5.29 & 7.75 & 57 \\
\hline Mixed reality & 4 & 1 & 2 & 1.41 & 4.69 & 23 \\
\hline System & 5 & 3 & 4 & 3.46 & 9.17 & 102 \\
\hline Social media & 3 & 2 & 2 & 2 & 2.45 & 8 \\
\hline Online education & 2 & 2 & 2 & 2 & 6.48 & 30 \\
\hline Gamification & 3 & 1 & 2 & 1.41 & 3.46 & 13 \\
\hline Context Aware & 2 & 1 & 1 & 1 & 2.24 & 5 \\
\hline Pattern recognition & 2 & 1 & 1 & 1 & 1 & 1 \\
\hline 3D modeling & 3 & 2 & 3 & 2.45 & 8.12 & 42 \\
\hline \multicolumn{7}{|c|}{ Period 2016-2019 } \\
\hline Technology acceptance & 6 & 2 & 3 & 2.45 & 3.46 & 12 \\
\hline Improvement & 6 & 2 & 2 & 2 & 2.45 & 7 \\
\hline Spatial orientation & 4 & 2 & 3 & 2.45 & 5.48 & 32 \\
\hline Instruction & 5 & 3 & 3 & 3 & 13.64 & 173 \\
\hline University & 6 & 1 & 1 & 1 & 1 & 2 \\
\hline Mobile & 12 & 2 & 3 & 2.45 & 3.74 & 15 \\
\hline Higher education & 68 & 8 & 16 & 11.31 & 11.31 & 294 \\
\hline Anatomy & 5 & 2 & 2 & 2 & 6.48 & 23 \\
\hline Usability & 5 & 2 & 2 & 2 & 3.46 & 8 \\
\hline Framework & 6 & 3 & 6 & 4.24 & 4.58 & 82 \\
\hline Virtual reality & 21 & 4 & 5 & 4.47 & 8 & 51 \\
\hline Attitude & 4 & 2 & 3 & 2.45 & 2.83 & 10 \\
\hline Blended learning & 4 & 0 & 0 & 0 & 0 & 0 \\
\hline Internet of things & 2 & 0 & 0 & 0 & 0 & 0 \\
\hline
\end{tabular}

The strategic diagram shows detailed information for each section, through a clustering process, from which a set of interconnected themes are obtained. These topics are obtained thanks to Callon's centrality, which measures the degree of interaction of a network with other networks. Centrality measures the strength of external links to other topics, being the measure of the importance of a topic in the development of the whole field of research analyzed; and to Callon's density, which measures the internal strength of the network, analyzing the internal links between all the key words that describe the research topic, this value being considered as the measure of the degree of development of the topic under study. From both parameters is born the strategic diagram, which is a two-dimensional space constructed through the graphic representation of themes according to their ranges of centrality and density (Figures 4 and 5).

With respect to the analysis of the strategic diagrams of the established periods, the themes of the first period (Figure 4) include "development", which focuses on professional groups, economic issues, the development of control systems, industry, water, electronics, telecommunications, and the information society; "tailored optical fibers", which is oriented toward simulators, reactions, inquiry, higher education, Tesla controllers, digital implementation, and linear accelerators; "mixed reality", which is aimed at educational methodologies, light immersion, maps, mobile augmented reality, telematic presence, and interior design; "pedagogy", which is related to mobile learning, autonomous learning, portable devices, mobile technology, online learning, ubiquitous computing, and architectural design; and "instruction", which is focused on teaching, physics, selection, environments, games, 
technology, education, and acceptance of the user. This period also highlights "virtual environments", which, although a basic and cross-cutting theme, is of great relevance to the scientific community, due to its high h-index. In the same way, during this period, "3D modeling" themes predominate. "3D modeling" focuses on photography and user interface. This category also includes "gamification", which is aimed at technological, mobile, and gaming information; "context aware", which is focused on image detection and mobile applications; "pattern recognition", focused on 3D and mathematics; and "systems", associated with educational research, open streets, mobile learning, human-computer interactions, and operational and educational engineering. This last topic belongs to an unknown profile, since its location in the diagram defines it as an emerging or disappearing theme.

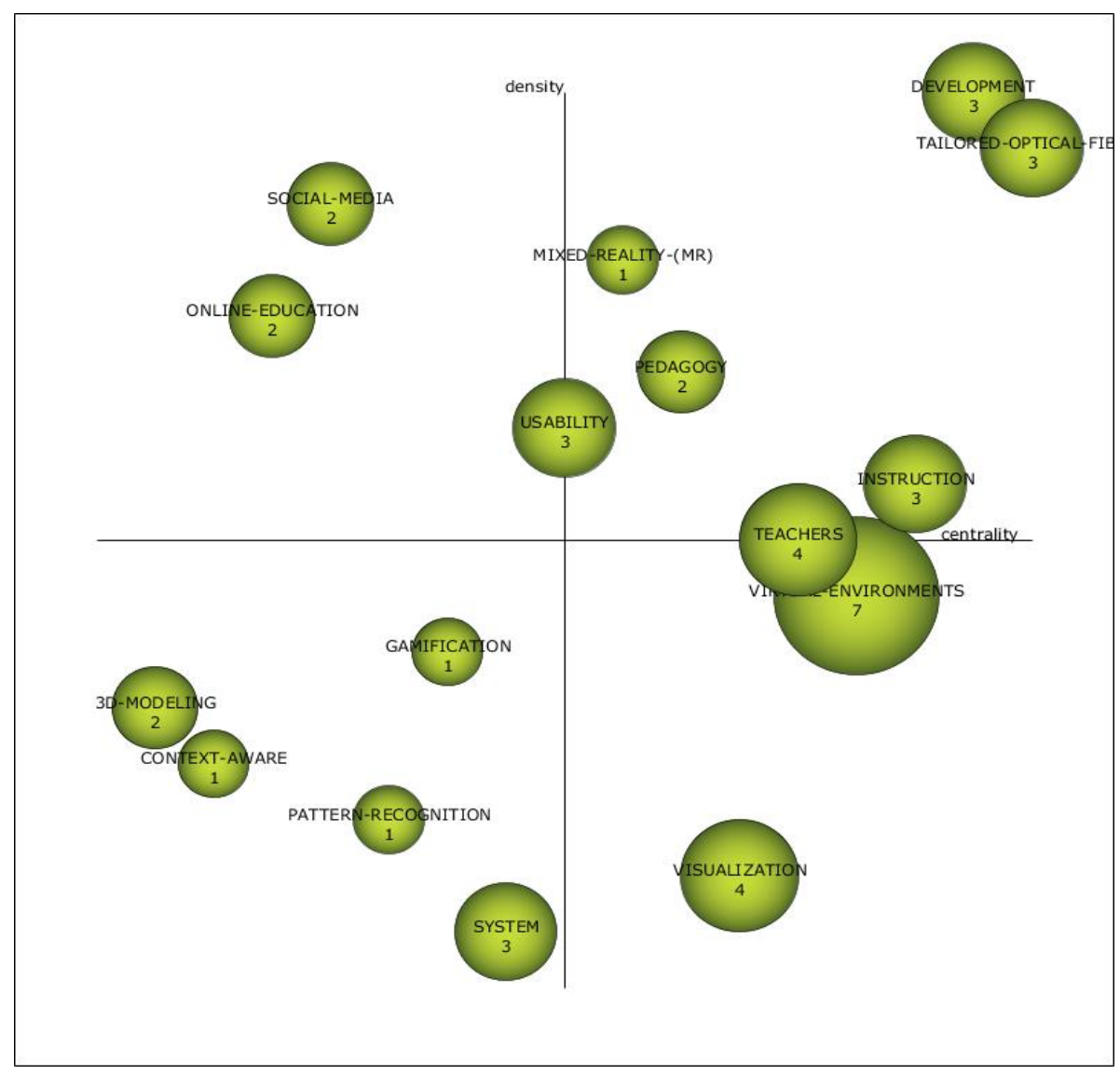

Figure 4. Strategic diagram by h-index: 1997-2015.

In the second period (Figure 5), the thematic engines include "technology acceptance", which refers to supports, experimental learning, sensor networks, remote laboratories, meta-analysis, mobile augmented reality, information, and students; "framework", which relates to building modeling, collaboration, context knowledge, simulation, strategies, industry 4.0, big data, and impact; "university", which is associated with development, skills, applications, English, acceptance, teaching-oriented technology, and gender; "instruction", which is linked to learning systems, designs, spatial capacity, performance, educational technology, education sciences, and cognitive load; "improve", focused on teaching, construction, youth, system, mobile technology, university students, interactive learning environments, and opportunity strategies; "mobile", which is related to architecture, ubiquitous learning, museums, technology, models, technological learning, and tools; and "higher education", which focuses on information and communication technologies, mobile learning, user acceptance, interface, perception, plans, flipped classrooms, and augmented reality. In addition, given its location as an emerging or missed topic, "anatomy", which is related to mathematics, accepted technological models, interactions, devices, visualization, pedagogy, learning, and teacher training, should be kept 
in mind. "Usability" is focused on interactivity, user experience, location, learning areas, motivation, cultural heritage and science; "attitude" relates to Pokémon Go, portable devices, and difficulties; "blended learning" is focused on gamification, social networks, QR codes, and online learning; and the "internet of things" relates to augmented reality and the training of engineers.

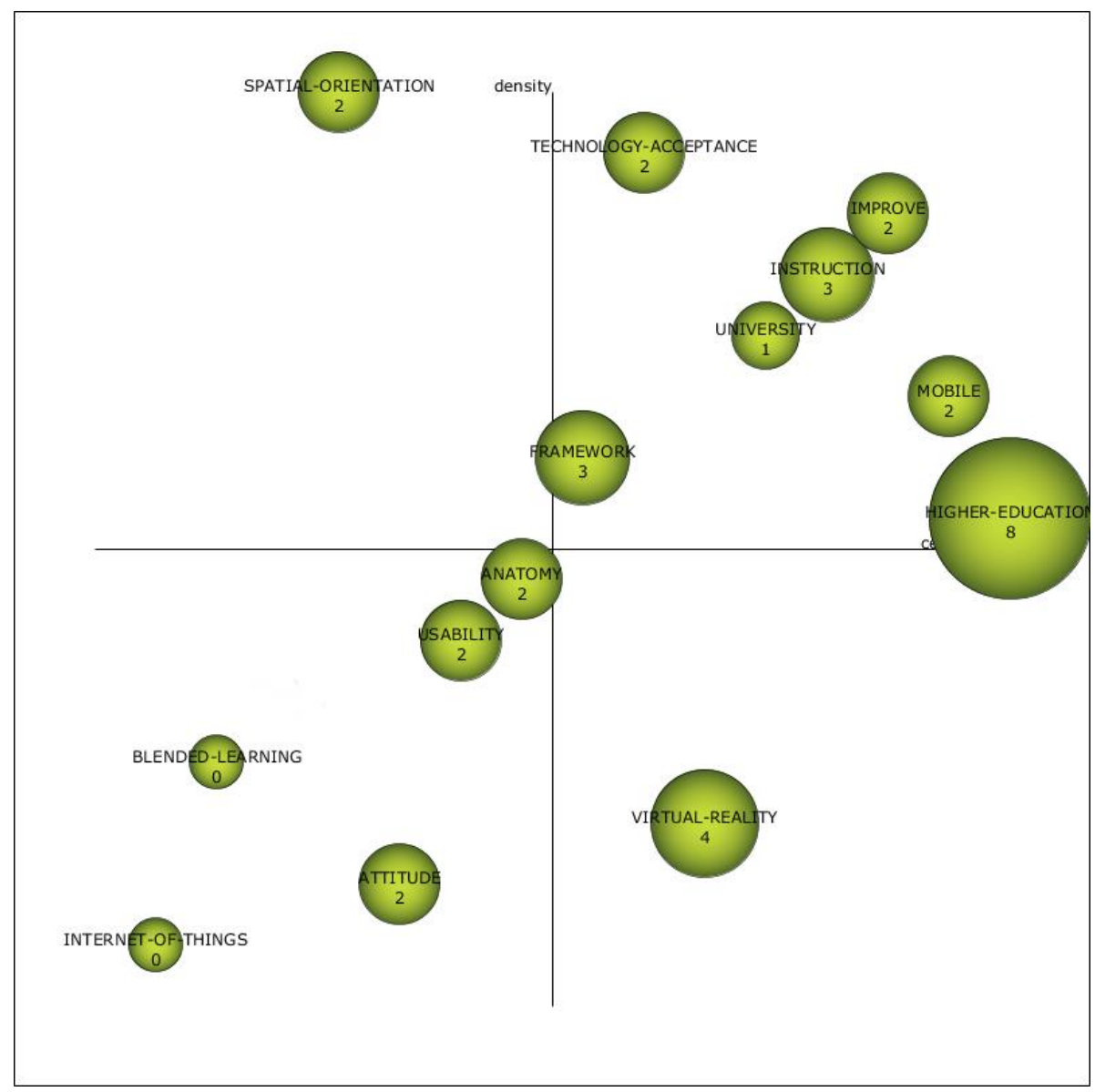

Figure 5. Strategic diagram by h-index: 2016-2019.

\subsection{Thematic Evolution of the Terms}

Considering the thematic evolution, which shows the strength of the evolutions produced in the main thematic areas between consecutive periods from the Jaccard index. Evolution exists if a theme of a period shares keywords with the consecutive theme. The more keywords two clusters of consecutive periods have in common, the more solid their evolution will be. It is necessary to take into account that two types of connections are established: one with a continuous line, whose link is thematic; and one with a dashed line, whose union is based on keywords. Likewise, the thickness of the lines marks the strength of the relationship between themes (Figure 6).

In studies on ARHE, significant thematic variety is observed, with continuity between "usability" and "instruction", since they are repeated in both periods. In the rest of the connections, they show conceptual leaps. There are many connections between the different periods, both conceptual and non-conceptual, but these connections have a weak relationship strength, since the widths of the lines are the lowest. Paying special attention to the topics with the highest h-index of each period, "virtual environments" (first period) connects-in a non-conceptual way-with "spatial orientation" and "higher education" (second period); the latter is conceptually related to "tailored optical fibers" and not conceptually related to "teachers", "instruction", "virtual environments", or "system". 


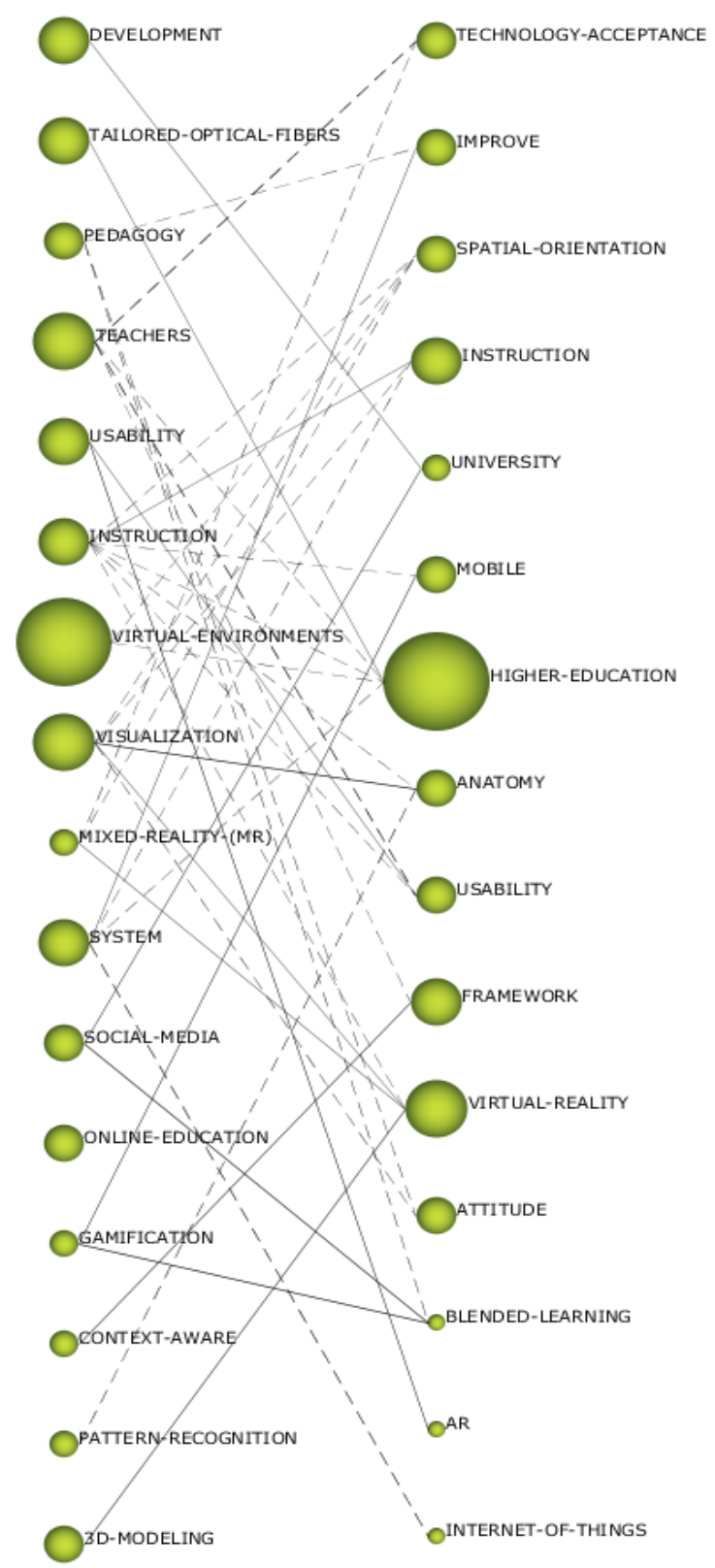

Figure 6. Thematic evolution by h-index.

\subsection{Authors with a Higher Relevance Index}

Attending to the people who investigate the field of ARHE (Figure 7), the motor authors (by their location in the diagram) most relevant to this field of study are Stoyanova, D., Naves, E.L.M., and Wozniak, P. In addition, Redondo, E., Martín-Gutiérrez, J. and Muñoz-Cristobal, J.A. must be taken into account, since, due to their location in the diagram, they can become motors or disappear. It is noteworthy that the authors with the highest $\mathrm{h}$ index are Redondo $(\mathrm{h}=3)$ and Martín-Gutiérrez $(\mathrm{h}=4)$. 


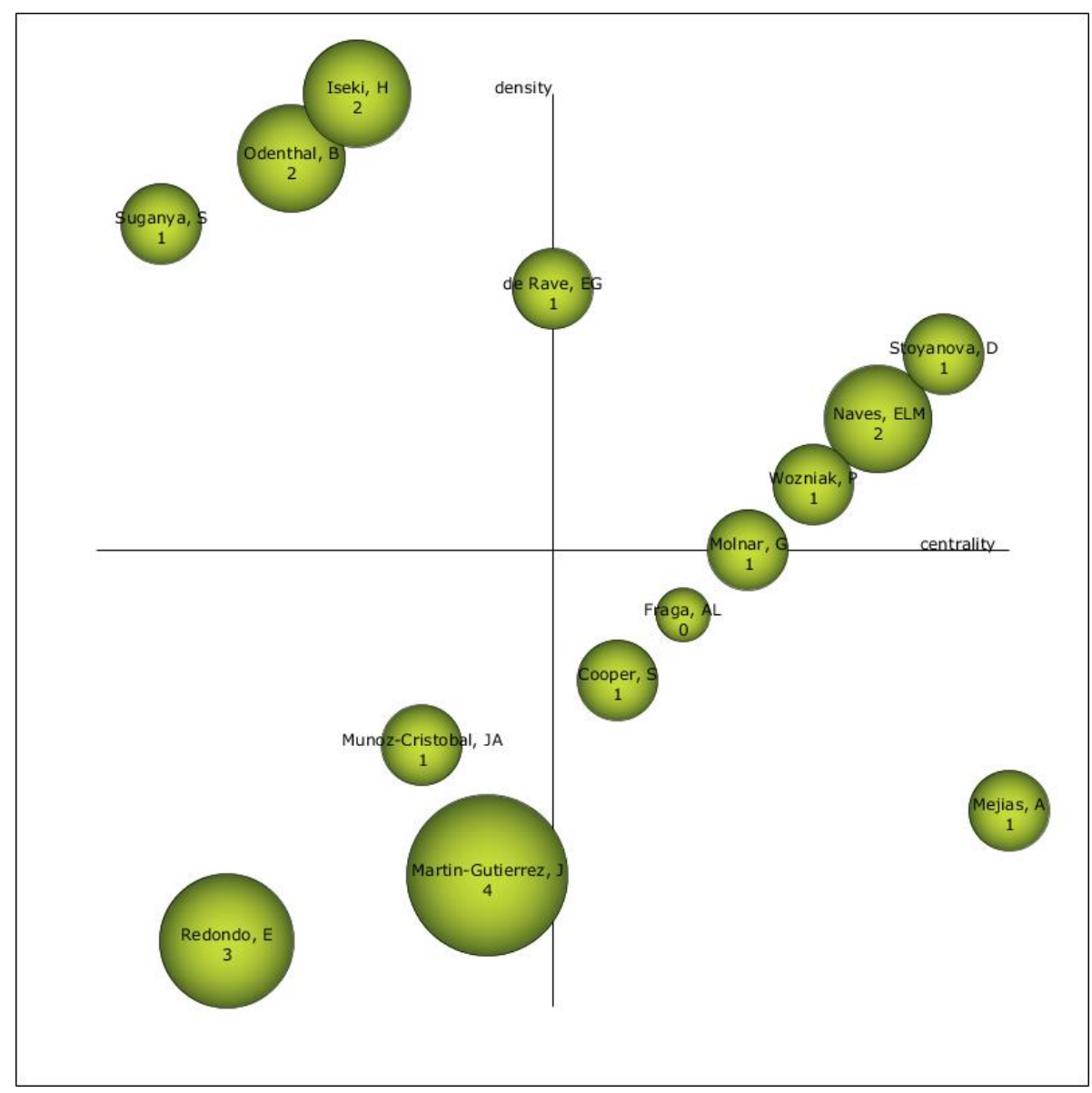

Figure 7. Strategic authoring diagram.

\section{Discussion and Conclusions}

As has been reflected in previous studies, AR has positioned itself as an emerging technology that yields a set of benefits in training processes. As a result, there is a need to explore its state of affairs in higher education from the perspective of WoS.

With regard to the bibliometric indicators defined in this study, starting with its scientific performance in ARHE, it is shown that ARHE is not abundant, although its production is not recent, since its beginnings date back to 1997. From then until now, its production has been inconstant due to the combination between productive years and recess years, with three different observable moments. In the first moment, dating from 1997 to 2008, production was not high (7.97\%), and there was no trend, being instead irregular. During a second period, from 2009 to 2014, production was more extensive $(21.74 \%)$, albeit with similar trends to the first period. The last period, which appears from 2015 to the present, was the most productive $(70.29 \%)$, with an upward trend (since the volume of publications is growing every year). These results are similar to those revealed in the literature, although the periods of higher production differ slightly, being established in 2012-2016 [35] and in 2015-2017 [33].

With regard to language, the one used by scientists to present their research is English, as found in other studies [33]. The studies are presented via communication and articles, evenly, with the first being slightly more common-results that are consistent with other studies that also add a paper as a type of relevant study [3], with quantitative studies being the main methodological choice [38]. For sources of origin, "INTED proceedings" (3.62\%) and "EDULEARN proceedings" (2.36\%) are the most common. The areas of knowledge where research on ARHE is presented are diverse, since there is an even production between "education educational research, computer science, and engineering", which determines the thematic variety of the established field of study. 
For the institutions, the Spanish are the pioneers of this type of study, since they take the top positions (highlighting the Universidad de La Laguna (3.08\%) and the Universidad de Sevilla (2.72\%)). It is worth noting that Martín-Gutiérrez J. (11 works), Redondo E. (9 works), Fonseca D. (10 works), and Cabero, J. (7 works) have provided the most research in this area and even the first two have the highest h-index (four and three, respectively), although they are not the most relevant in this subject. Instead, Stoyanova, D., Naves, E.L.M., and Wozniak, P. are the most relevant by its position in the diagram. The references that have the highest number of citations are [45,46] with 194 and 114 citations, respectively; these scientific texts are the ones that articulate the basis of the current state of research. Studies in the scientific literature have also found that Spain is one of the countries with the highest production in this field (18.66\%) [33], but Taiwan is also an important booming country [37]. In contrast, other studies cite the University of Science and Technology of Taiwan as the main institution and C.C. Tsai and G.J. Hwang as the most important authors [37].

Regarding the continuity of keywords between contiguous periods, it is revealed that only $28 \%$ of the keywords are repeated between both periods. The increase in the volume of keywords of the second period $(n=1165)$ with respect to the first $(n=703)$ stands out. Therefore, 970 new keywords are established in the second period.

The evolution of ARHE has not been regular nor has it settled on a single theme; instead, it has evolved over time and is currently in the process of establishing a solid line of research. This is reflected in the evolution between the periods established in this study, where between 1997 and 2015, the theme with the greatest bibliometric indicators was "virtual environments" (Works = 12; h-index = 7; g-index = 9; hg-index = 7.94; q2-index = 18.52; citations = 492), while between 2016 and 2019, "higher education" (Works $=68$; h-index $=8 ;$ g-index $=16$; hg-index $=11.31 ;$ q2-index $=11$.31; citations $=294$ ) occupied the top spot. In addition, the same themes are rarely repeated between the two periods.

If the motor themes of both periods are analyzed, the above postulation is confirmed; there is a thematic amalgam in both analyzed periods ("development", "tailored optical fibers", "mixed reality", "pedagogy", "instruction", "virtual environments", "3d modeling", " gamification", "context aware", "pattern recognition", "usability" and "systems" in the first period; "technology acceptance", "framework", "university", "instruction", "improve", "mobile", "higher education", "anatomy", "usability", "attitude", "blended learning", "internet of things" in the second period), whose relationship strength is weak. This shows that ARHE is generating an amplitude both in the field of knowledge and in the various branches of research, as well as conceptual gaps between the established periods. Only, a continuity has been found between "usability" and "instruction" that is repeated in both periods. These results are consistent with those other studies that have found there to be a great variety of research, highlighting the conceptualization of this phenomenon, the development of new RA methodologies, motivation and the attitude, special relocation, academic achievement, and the subjects in which the RA is studied [32,38].

The realization of this study helps to offer the scientific community the most relevant research fields in which ARHE is currently focused, in order to consolidate, in a diachronic manner, the research foundations upon which this emerging technology is based. Therefore, the analysis techniques used in this work provide an expanded and novel vision of the state of ARHE in WoS.

Therefore, this study allows an increase in the knowledge about the use of ARHE because it shows the scientific community where the state of the question about this emerging technology in said educational stage currently. In this way, the research trend so far on this area is shown, enabling researchers who want to study ARHE can select the topics considered relevant in this study and go to the most relevant bibliographic sources on the state of the matter.

The limitations of the study include the location of the references in which the WoS was not determined by keywords, in many cases hindering its localization process. Also, the low volume of scientific papers based on bibliometric analysis made it difficult to discuss the findings obtained in this study with those reported in the literature. This causes the results achieved in this investigation to acquire an exploratory character. This determines the existence of new findings in scientific research 
on ARHE. In this work, only the main findings obtained from the perspective of the WoS have been presented. For future research, we propose to carry out an investigation with the same structure on other databases, such as Scopus and Google Scholar.

Author Contributions: Conceptualization, S.P.S. and J.A.L.N.; methodology, J.L.B. and A.-J.M.-G; software, A.-J.M.-G.; formal analysis, J.L.B. and A.-J.M.-G.; investigation, J.L.B., A.-J.M.-G., J.A.L.N., and S.P.S.; data curation, S.P.S.; writing — original draft preparation, J.L.B. and S.P.S.; writing—review and editing, J.L.B. and A.-J.M.-G.; visualization, J.A.L.N. and S.P.S.; supervision, J.L.B and J.A.L.N.

Funding: This research received no external funding.

Acknowledgments: We acknowledge the researchers of the research group AREA (HUM-672), which belongs to the Ministry of Education and Science of the Junta de Andalucía and is registered in the Department of Didactics and School Organization of the Faculty of Education Sciences of the University of Granada.

Conflicts of Interest: The authors declare no conflict of interest.

\section{References}

1. Rodríguez, A.M.; Cáceres, M.P.; Alonso, S. La competencia digital del futuro docente: Análisis bibliométrico de la productividad científica indexada en Scopus. Int. J. Innov. Educ. Res. 2018, 10, 317-333.

2. Viñals, A.; Cuenca, J. El rol del docente en la era digital. Rev. Interuniv. Form. del Profr. 2016, 30, $103-114$.

3. Fombona, J.; Pascual, M.Á. La producción científica sobre Realidad Aumentada, un análisis de la situación educativa desde la perspectiva SCOPUS. EDMETIC 2017, 6, 39-61. [CrossRef]

4. Radu, I. Augmented reality in education: A meta-review and cross-media analysis. Pers. Ubiquitous Comput. 2014, 18, 1533-1543. [CrossRef]

5. Villalustre, L.; del Moral, M.E. Juegos perceptivos con realidad aumentada para trabajar contenido científico. Educ. Form. Tecnol. 2017, 10, 36-46.

6. Marín, V.; Muñoz, V.P. Trabajar el cuerpo humano con realidad aumentada en educación infantil. Rev. Tecnol. Cienc. y Educ. 2018, 9, 148-158.

7. Area, M.; Hernández, V.; Sosa, J.J. Modelos de integración didáctica de las TIC en el aula. Comunicar 2016, 24, 79-87. [CrossRef]

8. Castañeda, L.; Esteve, F.; Adell, J. ¿Por qué es necesario repensar la competencia docente para el mundo digital? RED 2018, 56, 1-20. [CrossRef]

9. Fuentes, A.; López, J.; Pozo, S. Analysis of the Digital Teaching Competence: Key Factor in the Performance of Active Pedagogies with Augmented Reality. REICE 2019, 17, 27-42. [CrossRef]

10. Castellanos, A.; Sánchez, C.; Calderero, J.F. Nuevos modelos tecnopedagógicos. Competencia digital de los alumnos universitarios. Rev. Electrn. Investig. Educ. 2017, 19, 1-9. [CrossRef]

11. Prendes, M.P.; Gutiérrez, I.; Martínez, F. Competencia digital: Una necesidad del profesorado universitario en el siglo XXI. RED 2018, 56, 1-22. [CrossRef]

12. Cabero, J.; Barroso, J. Los escenarios tecnológicos en Realidad Aumentada (RA): Posibilidades educativas en estudios universitarios. Aula Abierta 2018, 47, 327-336. [CrossRef]

13. Cabero, J.; Roig, R. The motivation of technological scenarios in augmented reality (AR): Results of different experiments. Appl. Sci. 2019, 9, 2907. [CrossRef]

14. Rodríguez, A.M.; Hinojo, F.J.; Ágreda, M. Diseño e implementación de una experiencia para trabajar la interculturalidad en Educación Infantil a través de realidad aumentada y códigos QR. Educar 2019, 55, 59-77. [CrossRef]

15. Chen, P.; Liu, X.; Cheng, W.; Huang, R. A review of using Augmented Reality in Education from 2011 to 2016. In Innovations in Smart Learning; Popescu, E., Kinshuk, M.K., Huang, R., Jemni, M., Chen, N.S., Sampson, D.G., Eds.; Springer: Singapore, 2017; pp. 13-18. [CrossRef]

16. Barroso, J.; Cabero, J.; García, F.; Calle, F.M.; Gallego, Ó.; Casado, I. Diseño, Producción, Evaluación y Utilización Educativa de la Realidad Aumentada, 1st ed.; Secretariado de Recursos Audiovisuales y NNTT de la Universidad de Sevilla: Sevilla, Spain, 2017; pp. 55-92. Available online: https://cutt.ly/5etacaZ (accessed on 2 December 2019).

17. Gómez, M.; Trujillo, J.M.; Aznar, I.; Cáceres, M.P. Augment reality and virtual reality for the improvement of spatial competences in Physical Education. J. Hum. Sport Exerc. 2018, 13, 189-198. [CrossRef] 
18. López, J.; Pozo, S.; López, G. La eficacia de la realidad aumentada en las aulas de infantil: Un estudio del aprendizaje de SVB y RCP en discentes de 5 años. Pixel-Bit 2019, 55, 157-178. [CrossRef]

19. Garay, U.; Tejada, E.; Castaño, C. Percepciones del alumnado hacia el aprendizaje mediante objetos educativos enriquecidos con realidad aumentada. EDMETIC 2017, 6, 145-164. [CrossRef]

20. Cabero, J.; Llorente, M.C.; Marín, V. Comunidades virtuales de aprendizaje. El Caso del proyecto de realidad aumentada: RAFODIUM. Perspect. Educ. 2017, 56, 117-138. [CrossRef]

21. Bacca, J.; Baldiris, S.; Fabregat, R.; Graf, S.; Kinshuk. Augmented reality trends in education: A systematic review of research and applications. Educ. Technol. Soc. 2014, 17, 133-149.

22. Marín, V.; Cabero, J.; Gallego, O.M. Motivación y realidad aumentada: Alumnos como consumidores y productores de objetos de aprendizaje. Aula Abierta 2018, 47, 337-346. [CrossRef]

23. Cheng, K.H. Reading an augmented reality book: An exploration of learners'cognitive load, motivation, and attitudes. Australas. J. Educ. Technol. 2017, 33, 53-69. [CrossRef]

24. Fombona, J.; Vázquez, E. Posibilidades de utilización de la Geolocalización y Realidad Aumentada en el ámbito educativo. Educ. XX1 2017, 20,319-342. [CrossRef]

25. Toledo, P.; Sánchez, J.M. Realidad Aumentada en Educación Primaria: Efectos sobre el aprendizaje. RELATEC 2017, 16, 79-92. [CrossRef]

26. Cabero, J.; Llorente, C.; Gutiérrez, J.J. Evaluación por y desde los usuarios: Objetos de aprendizaje con Realidad aumentada. RED 2017, 53, 1-17. [CrossRef]

27. Kamphuis, C.; Barsom, E.; Schijven, M.; Christoph, N. Augmented reality in medical education? Perspect. Med. Educ. 2014, 3, 300-311. [CrossRef]

28. Yuen, S.C.; Yaoyuneyong, G.; Johnson, E. Augmented Reality and Education: Applications and Potentials, 1st ed.; Springer: Berlin/Heidelberg, Germany, 2013; pp. 77-92. [CrossRef]

29. Prendes, C. Realidad aumentada y educación: Análisis de experiencias prácticas. Pixel-Bit. Rev. Medios Educ. 2015, 46, 187-203. [CrossRef]

30. Suh, A.; Prophet, J. The state of immersive technology research: A literature analysis. Comput. Hum. Behave. 2018, 86, 77-90. [CrossRef]

31. Muhamedyev, R.I.; Aliguliyev, R.M.; Shokishalov, Z.M.; Mustakayev, R.R. New Bibliometric Indicators for Prospectivity Estimation of Research Fields. Ann. Libr. Inf. Stud. 2018, 65, 1-8.

32. Fombona, J.; Pascual, M.Á.; González, M.C. M-learning y realidad aumentada: Revisión de literatura científica en el repositorio WoS. Comunicar 2017, 25, 63-72. [CrossRef]

33. Lorenzo, G.; Scagliarini, C. Bibliometric review of augmented reality in education. Rev. Gen. Inf. Doc. 2018, 28, 45-60. [CrossRef]

34. Heradio, R.; de la Torre, L.; Galán, D.; Cabrerizo, F.J.; Herrera, E.; Dormido, S. Virtual and remote labs in education: A bibliometric analysis. Comput. Educ. 2016, 98, 14-38. [CrossRef]

35. Álvarez, A.; Castillo, M.; Geldes, C. Análisis Bibliométrico de la Realidad Aumentada y su Relación con la Administración de Negocios. Inf. Tecnol. 2017, 28, 57-66. [CrossRef]

36. Jaramillo, A.M.; Silva, G.J.; Adarve, C.A.; Velásquez, S.M.; Páramo, C.A.; Gómez, L.L. Aplicaciones de Realidad Aumentada en educación para mejorar los procesos de enseñanza-aprendizaje: Una revisión sistemática. Rev. Espac. 2018, 39, 1-15.

37. Karakus, M.; Ersozlu, A.; Clark, A.C. Augmented Reality Research in Education: A Bibliometric Study. J. Math. Sci. Technol. Educ. 2019, 15,1-12. [CrossRef]

38. Arici, F.; Yildirim, P.; Caliklar, S..; Yilmaz, R.M. Research trends in the use of augmented reality in science education: Content and bibliometric mapping analysis. Comput. Educ. 2019, 142, 1-13. [CrossRef]

39. Martínez, M.A.; Cobo, M.J.; Herrera, M.; Herrera, E. Analyzing the scientific evolution of social work using science mapping. Res. Soc. Work Pract. 2015, 25, 257-277. [CrossRef]

40. Moreno, A.J. Estudio Bibliométrico de la Producción Científica sobre la Inspección Educativa. REICE. Rev. Iberoam. Sobre Calid. Efic. Cambio Educ. 2019, 17, 23-40. [CrossRef]

41. López-Robles, J.R.; Otegi-Olaso, J.R.; Porto, I.; Cobo, M.J. 30 years of intelligence models in management and business: A bibliometric review. Int. J. Inf. Manag. 2019, 48, 22-38. [CrossRef]

42. Rodríguez-García, A.M.; López, J.; Agreda, M.; Moreno-Guerrero, A.J. Productive, Structural and Dynamic Study of the Concept of Sustainability in the Educational Field. Sustainability 2019, 11, 5613. [CrossRef]

43. Hirsch, J.E. An index to quantify an individual's scientific research output. Proc. Natl. Acad. Sci. USA 2005, 102, 16569-16572. [CrossRef] 
44. Cobo, M.J.; López, A.G.; Herrera, E.; Herrera, F. Science mapping software tools: Review, analysis, and cooperative study among tools. J. Am. Soc. Inf. Sci. Technol. 2011, 62, 1382-1402. [CrossRef]

45. Kaufmann, H.; Schmalstieg, D. Mathematics and geometry education with collaborative augmented reality. Comput. Graphics 2002, 23, 339-345. [CrossRef]

46. Martín-Gutiérrez, J.; Saorín, J.L.; Contero, M.; Alcaniz, M.; Pérez-López, D.C.; Ortega, M. Design and validation of an augmented book for spatial abilities development in engineering students. Comput. Graphics 2010, 34, 77-91. [CrossRef]

47. Akcayir, M.; Akcayir, G. Advantages and challenges associated with augmented reality crossMark for education: A systematic review of the literature. Educ. Res. Rev. 2017, 20, 1-11. [CrossRef]

48. Potkinjak, V.; Gardner, M.; Callaghan, V.; Mattila, P.; Guetl, C.; Petrovic, V.M.; Jovanovic, K. Virtual laboratories for education in science, technology, and engineering: A review. Comput. Educ. 2016, 95, 309-327. [CrossRef]

49. Andujar, J.M.; Mejías, A.; Márquez, M.A. Augmented Reality for the Improvement of Remote Laboratories: An Augmented Remote Laboratory. IEEE Trans. Educ. 2011, 53, 492-500. [CrossRef]

(C) 2019 by the authors. Licensee MDPI, Basel, Switzerland. This article is an open access article distributed under the terms and conditions of the Creative Commons Attribution (CC BY) license (http://creativecommons.org/licenses/by/4.0/). 